\title{
Autocrine prolactin: an emerging market for homegrown (prolactin) despite the imports
}

\begin{abstract}
Senthil K. Muthuswamy ${ }^{1}$
Prolactin (PRL) is a peptide hormone that is produced by the pituitary gland and is known to regulate lactogenic differentiation. There is a significant body of evidence that points to autocrine production of prolactin and activation of an autocrine/paracrine signaling pathway to regulate cell proliferation and migration and inhibition of cell death. This perspective highlights the recent study in the October 1, 2012, issue of Genes \& Development by Chen and colleagues (pp. 2154-2168) that describes a mechanism for autocrine prolactin production and places the finding in the context of a role for prolactin in breast development and cancer.
\end{abstract}

Ontario Cancer Institute, Princess Margaret Hospital, Campbell Family Institute for Breast Cancer Research, University of Toronto, Toronto, Ontario M5G 2M9, Canada; Cold Spring Harbor Laboratory, Cold Spring Harbor, New York 11724, USA 1997).
Prolactin (PRL) was discovered $>80$ years ago and is best known for its role in lactation (Ben-Jonathan et al. 2007). It is a $23-\mathrm{kDa}$ secreted peptide hormone that is 199 amino acids long. Lactotrope cells in the pituitary gland synthesize, store, and release prolactin into the blood circulation (Ben-Jonathan et al. 2007). The synthesis and secretion of prolactin by the lactotrope cells is tightly regulated by multiple factors; of particular note is the inhibitory effect by dopaminergic neurons. Dopamine can inhibit both the transcription of prolactin mRNA and the secretion of prolactin protein (Ben-Jonathan and Hnasko 2001). Consistent with this notion, dopamine antagonists increase serum prolactin levels, causing hyperprolactemia (Meltzer and Fang 1976; Wieck and Haddad 2002). Direct insights into prolactin function are derived from studies performed in rodents. Homozygous deletion of the prolactin gene in mice results in a loss of lobular decoration in virgin mammary glands, with no apparent changes in development of the mammary ductal network. In addition, prolactin ${ }^{-/-}$mice show defective lobuloalveolar development during pregnancy but do not display any other overt symptoms, thus identifying the modulation of mammary differentiation as the primary function for

[Keywords: Pten; Akt; Stat5; mammary gland; lactation; differentiation] ${ }^{1}$ Correspondence

E-mail s.muthuswamy@utoronto.ca

Article is online at http://www.genesdev.org/cgi/doi/10.1101/gad.204636.112. prolactin secreted by the pituitary gland (Horseman et al.

Although the pituitary gland is the major source of prolactin synthesis, extrapituitary cells such as decidual cells, adipocytes, $\mathrm{T}$ lymphocytes, mononuclear cells, and breast cancer-derived cells (discussed below) also produce prolactin (Ben-Jonathan et al. 1996). Unlike the lactotrope cells in the pituitary gland that have a large capacity to store synthesized prolactin, extrapituitary prolactin is likely regulated at the level of transcription or translation and not at the level of release from vacuolar stores. Interestingly, transcription of prolactin mRNA synthesized in extrapituitary sites is regulated by an alternative promoter and initiates $5.8 \mathrm{~kb}$ upstream of the initiation site used in lactotrope cells (Gerlo et al. 2006). Although the alternative initiation site results in inclusion of a novel exon (exon 1a), the exon is part of the $5^{\prime}$ untranslated region and does not change any amino acids of the encoded protein (Gerlo et al. 2006). As expected, the extrapituitary prolactin synthesis is not sensitive to dopamine, and addition of the dopamine agonist bromocryptine does not inhibit production of prolactin by cells in culture (Gerlo et al. 2006). Less is known about the regulatory mechanisms that control expression of prolactin at extrapituitary sites. In addition, the role played by extrapituitary prolactin during normal physiology is poorly understood.

The prolactin receptor (PRLR) is a $90-\mathrm{kDa}$ protein consisting of 622 amino acids that belongs to the type I class of transmembrane receptors. It has a 210-aminoacid ligand-binding extracellular domain with two type III fibronectin-like domains and multiple sites for $\mathrm{N}$-linked glycosylation (Ben-Jonathan et al. 2007). The 364-aminoacid intracellular domain has no intrinsic kinase activity or homology with known domains but has a 9-amino-acid proline-rich region (amino acids 267-275), termed the Box1 motif. Ligand binding is thought to induce either dimerization of the receptor or a change in the conformation of a preformed receptor dimer, which activates the associated cytoplasmic tyrosine kinase Janus kinase 2 (Jak2) (Campbell et al. 1994; Dusanter-Fourt et al. 1994; Rui et al. 1994; Frank 2002). While Jak2 associates with the receptor in a prolactin-independent manner, prolactin 
stimulation is required for tyrosine phosphorylation and activation of Jak2 (DaSilva et al. 1994). Prolactin-dependent activation of Jak2 induces phosphorylation of the prolactin receptor at multiple tyrosine residues, which mediates recruitment and activation of signal transducer and activator of transcription 5 (STAT5a and STAT5b), STAT1, and STAT3 (David et al. 1994; Gouilleux et al. 1994; Wakao et al. 1994). STAT5a and STAT5b are the primary effectors of prolactin signaling and are critical for inducing transcription of genes encoding milk proteins in mammary epithelial cells. In addition to Jak2, prolactin also stimulates activation of c-Src, Fyn, and Tec family tyrosine kinases (Clevenger 2003); mitogen-activated protein kinase (MAPK); and Akt. While MAPK and Akt are thought to regulate cell proliferation and cell death pathways in response to prolactin stimulation, neither of the pathways is critical for prolactin-induced milk protein expression (Clevenger 2003).

Alternative splicing generates multiple prolactin receptor isoforms that differ in the length of the intracellular domain. In addition to the full-length receptor, human cells express five different isoforms. One of the isoforms lacks the transmembrane domain, is secreted from cells, and may function as a decoy receptor. All of the isoforms with a short cytoplasmic tail retain the ability to interact with Jak2 but differ in their ability to mediate prolactin-induced cell proliferation (Ben-Jonathan et al. 2007). Rodents have fewer prolactin receptor isoforms than humans. In addition to the-full length receptor, rat cells express two isoforms, and mouse cells express one (Ben-Jonathan et al. 2007). Isoform expression varies in a tissue-specific manner and is also differentially regulated during development and physiological states such as estrous cycle, pregnancy, and lactation in mice (Jahn et al. 1991; Nagano and Kelly 1994; Bole-Feysot et al. 1998). Neither the mechanisms nor the importance of PRLR isoform switching are well understood. However, homozygous deletion of the prolactin receptor gene in mice results in multiple and significant defects in the reproductive system, including a complete failure to lactate during first pregnancy (Ormandy et al. 1997), thus demonstrating a dominant role for prolactin signaling in reproductive biology.

\section{Autocrine prolactin and mammary gland biology}

As discussed above, a role for endocrine prolactin during mammary gland differentiation is well established. However, there is reason to believe that autocrine prolactin is also an important regulator of physiology in mammary epithelial cells. Transplantation of prolactin $^{-/-}$mammary epithelial cells into mammary fat pads of immunocompromised $\mathrm{Rag}^{-/-}$hosts resulted in a 2.8-fold decrease in cell proliferation during lactation, whereas transplantation of $\mathrm{Rag}^{-/-}$mammary epithelium into prolactin ${ }^{-/-}$ hosts did not affect proliferation (Naylor et al. 2003), suggesting that mammary epithelial cells may need autocrine prolactin during normal physiology. Yet we do not know whether and how epithelial prolactin is produced and whether it regulates a prolactin receptor- mediated signaling pathway by creating an autocrine loop.

In the October 1, 2012, issue of Genes \& Development, Chen et al. (2012) report on a meticulously performed study in which they discovered an unexpected role for autocrine prolactin secreted by mammary epithelial cells during Akt-induced lactogenic differentiation. Acute tetracycline-inducible expression of Akt in MMTV-rtTA; TetO-Akt1 (MTB/tAkt) transgenic mice promoted STAT5 phosphorylation, formation of lipid droplets, and synthesis of milk proteins similar to that observed on day 2 of lactation in wild-type mice. In addition to activating Akt as a transgene, activation of endogenous Akt by homozygous loss of $P_{T E N^{-/}}$also induced expression of milk proteins and formation of lipid droplets. Furthermore, transplantation of MTB/tAkt mammary epithelial cells into wild-type mice or in vitro culturing of transgenic mouse-derived primary mammary epithelial cells also resulted in increased STAT5 phosphorylation, thus demonstrating that Aktinduced STAT5 activation is an epithelial cell-intrinsic phenomenon and does not require paracrine signaling from the stroma. Expression of MTB/tAkt in STAT5a/b $b^{-1-}$ mice failed to induce milk protein expression and lactogenic differentiation, demonstrating that STAT5a/b activation is a required step for the Akt-induced lactogenic differentiation observed in virgin mammary glands.

Expression of Akt in prolactin receptor ${ }^{-/}$mice failed to induce STAT5 activation, demonstrating that prolactin receptor was required for Akt-induced activation of STAT5. Treatment with conditioned medium (CM) from $\mathrm{MTB} / t A k t, \mathrm{MTB} / t A k t / S T A T 5 a / 5 b$, or prolactin receptor transgenic mammary gland-derived cells induced STAT5 phosphorylation in HC11 mammary epithelial cells. These observations raise the possibility of the presence of a secreted factor induced by $\mathrm{MTB} / t A K T$-independent of STAT5 and prolactin receptor signaling — that can induce STAT5 activation. Given the requirement for the prolactin receptor for activation of STAT5, Chen et al. (2012) observed detectable expression of prolactin in the mammary glands of MTB/tAkt or PTEN ${ }^{f l / f 1}$ mice. To directly test whether prolactin is needed for the MTB/tAktinduced biology, they crossed $\mathrm{MTB} / t A k t$ mice into a prolactin $^{-/-}$background and demonstrated that MTB/ tAkt-induced prolactin expression is required for the lactogenic differentiation and milk protein expression observed in virgin mammary glands.

Interestingly, circulating prolactin levels were not altered in tetracycline-induced $\mathrm{MTB} / t A k t$ mice, and purified epithelial cell-derived mammary glands expressed prolactin, suggesting autocrine production of prolactin by epithelial cells. To directly test whether epithelial cells make prolactin, the investigators transplanted epithelial cells from $\mathrm{MTB} / \mathrm{tAkt} /$ prolactin $^{-/-}$and MTB/tAkt/ prolactin $^{+/+}$mice into wild-type mammary glands. Mammary outgrowth from MTB/tAkt/prolactin ${ }^{-/-}$epithelial cells failed to show STAT5 phosphorylation and lactogenic differentiation, while the $\mathrm{MTB} /$ tAkt/prolactin $^{+/+}$ cells retained their ability to undergo lactogenic differentiation and phosphorylate STAT5. The lack of differentiation of prolactin ${ }^{-/-}$cells transplanted into wild-type mice 
demonstrates the inability of endocrine prolactin produced by the pituitary gland to compensate for the lack of prolactin gene in the transplanted epithelial cells, thus demonstrating the requirement for autocrine prolactin made by epithelial cells.

It is likely that the observations made using transgenic mice are highly relevant for normal physiology: Transplantation of $A t k 1^{-1-} / A k t 2^{+/-}$epithelium into the mammary fat pads of wild-type mice showed decreased milk protein expression and reduced STAT5 activation, whereas transplantation of wild-type epithelium into Atk $1^{-/-} / \mathrm{Akt}^{+/-}$mammary fat pads induced normal lactogenic differentiation and STAT5 activation. These results thus demonstrate the importance of Akt-regulated autocrine prolactin production in mammary epithelial cells during normal physiology. This extends a previous study by the investigators (Chen et al. 2010), which reports that $A k t 1^{-1-} / \mathrm{Akt2}^{+-}$epithelial cells show up-regulation of caveolin and SOCS2, negative regulators of the Jak/STAT signaling pathway. Interestingly, while an increase in prolactin protein was clearly detected, the prolactin mRNA was not altered in MTB/tAkt glands, suggesting that Akt regulates prolactin expression post-transcriptionally. These observations demonstrate a role for Aktmediated activation of autocrine prolactin synthesis in mammary epithelial cells. Akt signaling is an important regulator of cancer cell growth, survival, and metabolism; thus, the above study raises the possibility of a role for Akt-regulated autocrine prolactin synthesis in cancer.

\section{Prolactin and breast cancer}

A role for prolactin signaling in cancer has long been recognized. The prolactin receptor is expressed in almost all cell types and in $70 \%$ of breast cancer samples (Vonderhaar 1989). Early studies demonstrated that physiological concentrations of prolactin could induce proliferation of primary human breast tumors in organ culture and tumor-derived primary cells in culture (Welsch et al. 1979; Malarkey et al. 1983). In addition, prolactin induces proliferation of breast cancer-derived cell lines such as MCF-7 and T47D under serum-free conditions or in the presence of charcoal-stripped serum (Biswas and Vonderhaar 1987; Vonderhaar 1999|. MCF-7 and T47D breast cancerderived cells also synthesize bioactive prolactin in an autocrine manner (Ginsburg and Vonderhaar 1995), and prolactin mRNA expression can be detected in primary human breast cancers (Clevenger et al. 1995). These observations raise the possibility that cancer cells produce autocrine prolactin and create an autocrine loop of prolactin/prolactin receptor signaling.

\section{Cell biology}

While the most prominent role of prolactin is the regulation of lactogenic differentiation in mammary epithelial cells, the hormone also promotes cell proliferation, inhibits cell death, and promotes cell migration /Clevenger 2003). The recognition of a prolactin/prolactin receptor autocrine signaling loop that induces cell proliferation arose from early studies from the Vonderhaar laboratory (Ginsburg and Vonderhaar 1995), where they demonstrated that prolactin-neutralizing antibodies inhibited proliferation of MCF-7 cells. Furthermore, prolactin induces expression of cyclin D1 by stimulating Jak2 and STAT5a/bmediated transcriptional activation of the cyclin D1 promoter (Schroeder et al. 2002; Brockman and Schuler 2005). Jak2 is required for both prolactin-induced transcription of cyclin D1 and retention of cyclin D1 in the nucleus (Sakamoto et al. 2007). PI 3-kinase enhancer A (PIKE-A) interacts with prolactin receptor and STAT5 to form a prolactin receptor/Pike-A/STAT5 protein complex. This complex is required for prolactin-induced activation of STAT5 and cyclin D1 expression but is not required for prolactin-induced activation of Jak2 (Chan et al. 2010). In addition to Jak2, prolactin stimulation can also activate Jak1 in a Jak2-independent manner. Down-regulation of Jak1 interferes with prolactin-induced activation of MAPK and STAT3 and activation of Jak2, suggesting a role for Jak1 as an activator of STAT3 and also as an enhancer of the Jak2-STAT5 pathway (Neilson et al. 2007). Prolactin can also induce proliferation of mammary epithelial cells by a Jak2-independent, Src tyrosine kinase-dependent manner, whereby prolactin induces activation of a Src/focal adhesion kinase/Erk1/2 pathway and also activates the PI3K pathway to induce expression of cyclin D1 and Myc to promote cell proliferation (Acosta 2003). In addition to its effect on mammary epithelial cells, prolactin also induces proliferation of $\mathrm{T}$ lymphocytes and prostate epithelial cells (not discussed here; for a thorough review, see Clevenger 2003; Ben-Jonathan et al. 2007). Thus, activation of the prolactin/prolactin receptor signaling pathway can be a potent mitogenic signal in cancer cells that express autocrine prolactin.

In addition to promoting cell proliferation, prolactin can function as a chemoattractant for breast cancerderived cell lines (Maus et al. 1999). Prolactin interacts with and activates the kinase activity of Nek3 (never in mitosis A-related kinase 3 ) and promotes an interaction between the prolactin receptor Nek3 and Vav2, a GTP exchange factor (Miller 2005), to increase Rac GTP levels in mammary epithelial cells. Nek3 is required for prolactin-induced actin reorganization and cell motility and invasion (Miller et al. 2007). In addition, prolactin-stimulated Jak2 kinase phosphorylates the P21-activated kinase Pak1 (Rider et al. 2007). Active Pak1 induces phosphorylation of filamin A, an actin-binding protein that promotes cross-linking of cortical actin filaments to promote membrane ruffling and cell migration (Rider and Diakonova 2011). Interestingly, prolactin receptor expression is associated with breast cancer progression, suggesting a likely relationship between prolactin receptor signaling and metastatic progression. However, evidence demonstrating a critical role for prolactin/prolactin receptor signaling and metastatic progression in vivo remains to be uncovered.

\section{Rodent models}

Consistent with its role in promoting cell proliferation, prolactin is a well-known regulator of mammary cancer 
in rodent models (Welsch and Nagasawa 1977). Increasing prolactin levels by daily injections of prolactin increases the spontaneous incidence of mammary tumors (Boot et al. 1962). In addition, chemical carcinogen-induced mammary tumor incidence in different rat strains positively correlates with concentrations of serum prolactin levels (Boyns et al. 1973). Mammary tumors induced by nitrosomethyl urea (NMU) secrete autocrine prolactin, and anti-prolactin antibodies inhibit proliferation in an NMU-induced mammary tumor-derived cell line, suggesting a role for prolactin as a local mitogen in rat mammary tumors (Mershon et al. 1995). Direct evidence for the ability of prolactin to induce transformation of mammary epithelial cells in mice comes from experiments performed using transgenic mice. Expression of prolactin, but not growth hormone, in mammary epithelial cells induced development of nonmetastatic, mammary adenocarcinomas with tubular and squamous differentiation phenotypes (Wennbo et al. 1997). In addition, expression of prolactin under the control of neurelated lipocalin (NRL) promoter-a mammary-selective, hormonally nonresponsive promoter-induces hyperplastic growth of the mammary gland by 9 mo of age that progresses to develop $\mathrm{ER} \alpha^{+}$and $\mathrm{ER} \alpha^{-}$mammary tumors of varying histopathology with signs of invasive behavior (Rose-Hellekant et al. 2003). Despite their histological differences, the NRL-prolactin-induced tumors tend to belong to the estrogen-resistant luminal subtype of breast cancer (Arendt et al. 2011). Interestingly, overexpression of prolactin under the control of whey acidic protein promoter (WAP) does not induce mammary carcinogenesis, suggesting that the differentiation state of cells in which prolactin is overexpressed may influence the ability of prolactin to induce tumorigenesis (Manhes 2006). In addition to initiating transformation by itself, prolactin also cooperates with other prominent regulators of mammary tumorigenesis. Coexpression of NRL-prolactin and an EGF family growth factor, TGF $\alpha$, significantly shortens the development of macrocystic lesions and adenocarcinomas (Arendt et al. 2006). Together, these studies highlight an important aspect of prolactin biology: While prolactin/prolactin receptor signaling promotes lactogenic differentiation of mammary epithelial cells, aberrant activation of prolactin/prolactin receptor signaling can transform mammary epithelial cells and induce mammary tumors.

\section{Human breast cancer}

For a long time, it was thought that prolactin's relationship to cancer is a rodent-specific phenomenon. This notion has been challenged, and there is now a significant body of evidence that identifies prolactin as an important player in human breast cancer. Initial evidence came from a study involving 424 patients in which women with more than a median value of serum prolactin showed a 2.0-fold higher risk of developing breast cancer (Ingram et al. 1990). A larger case-controlled prospective study as part of the Nurses' Health Study (NHS) that included 306 post-menopausal women who were diagnosed with breast cancer and 448 control subjects demonstrated that women with high (upper quartile) serum prolactin levels had a 2.0-fold increased risk of developing breast cancer compared with those with low (bottom quartile) serum prolactin levels (Hankinson et al. 1999). A more recent study involving 377 cases of breast cancer with two controls for each case, matched for age and menopausal status, also show a 1.3-fold increase in patients with high (upper quartile) serum prolactin levels (Tworoger et al. 2007). In addition to these, there are now multiple studies that support the positive correlation between high serum prolactin levels and increased breast cancer risk in both premenopausal and post-menopausal women (for a review, see Harvey 2011).

As discussed above, dopamine is a key inhibitor of prolactin secretion from the pituitary gland. Given the large increase in the use of dopamine antagonists for treating psychological disorders, it raises the possibility of the relationship between use of psychotic drugs, serum prolactin levels, and cancer risk. A large, retrospective study involving $>52,819$ patients exposed to dopamine antagonists and 55,289 not exposed to dopamine antagonists demonstrated that use of dopamine antagonists was associated with a $16 \%$ increase in breast cancer with no effect on the incidence of colon cancer in the same patient cohort. The patients were tumor-free at the time they were enrolled in the study, suggesting a positive relationship with the use of dopamine antagonists and breast cancer risk (Wang et al. 2002).

In addition to its role during tumor initiation and progression, prolactin can also augment oncogenic signaling by EGFR and ErbB2/HER2, members of the EGF family of receptor tyrosine kinases that play important roles in breast cancer. Prolactin stimulation induces Erk2-mediated phosphorylation of EGFR and ErbB2 (Huang et al. 2006). In addition, in ErbB2-overexpressing breast cancer cells, autocrine prolactin-mediated activation of Jak2 induced tyrosine phosphorylation of ErbB2, recruitment of Grb2, activation of MAPK, and induction of cell proliferation. Inhibition of Jak2 decreased prolactin-induced phosphorylation of ErbB2, suggesting a possible cross-talk between prolactin and ErbB2 signaling pathways during proliferation of breast cancer cell lines (Yamauchi 2000). Inhibition of the prolactin receptor using G129R (prolactin receptor antagonist) inhibits ErbB2 phosphorylation, suggesting an opportunity for combination therapy. Consistent with this possibility, combination of Herceptin (anti-HER2 therapeutic antibody) and G129R has an additive effect in inhibiting both MAPK activation and growth of BT474 breast cancer cells in cell culture and in xenograft mouse models (Scotti et al. 2008). Further studies are needed to explore this novel therapeutic strategy for patients with HER-positive breast cancers that also express autocrine prolactin.

Recent studies point to a possible role for prolactin signaling in chemoresistance. Prolactin stimulation induces expression of the anti-apoptotic protein Bcl-2 in multiple breast cancer-derived cell lines (Beck et al. 2002), suggesting a role for prolactin signaling in inhibiting apoptosis. In addition, prolactin stimulation inhibits cisplatin-induced cell cycle arrest by activating glutathione-S-transferase, 
a detoxifying enzyme that blocks the ability of cisplatin to enter the nucleus (LaPensee et al. 2009). Well-conducted animal studies will be needed to better understand the role prolactin plays during drug resistance. Furthermore, it is not clear whether endocrine and autocrine regulation of prolactin differentially regulate cell death and chemoresistance pathways.

Thus, although most of our understanding of prolactin biology stems from studying its endocrine function, there is an emerging interest in understanding the regulation of autocrine prolactin in both normal and cancer epithelia. Given that most cell types express prolactin receptor, signals that induce production of autocrine prolactin will result in activation of an autocrine/paracrine signaling loop that will impact proliferation, survival, and differentiation of cells. Furthermore, the ability of prolactin to induce phosphorylation of ErbB2, an oncogenic receptor tyrosine, raises the possibility that the effect of activating a prolactin/prolactin receptor autocrine signaling loop will have implications beyond prolactin signaling and biology. Last, recognizing the importance of autocrine prolactin will change the way we consider targeting this pathway. For example, targeting the prolactin receptor would be a better choice for therapeutics compared with using dopamine agonists to inhibit pituitary prolactin production.

\section{Acknowledgments}

I thank Drs. Jennifer Haynes and Shereen Ezzat for critical reading and helpful comments.

\section{References}

Acosta JJ. 2003. Src mediates prolactin-dependent proliferation of T47D and MCF7 cells via the activation of focal adhesion kinase/Erk1/2 and phosphatidylinositol 3-kinase pathways. Methods Enzymol 17: 2268-2282.

Arendt LM, Rose-Hellekant TA, Sandgren EP, Schuler LA. 2006. Prolactin potentiates transforming growth factor $\alpha$ induction of mammary neoplasia in transgenic mice. Am I Pathol 168: 1365-1374.

Arendt LM, Rugowski DE, Grafwallner-Huseth TA, GarciaBarchino MJ, Rui H, Schuler LA. 2011. Prolactin-induced mouse mammary carcinomas model estrogen resistant luminal breast cancer. Breast Cancer Res 13: R11. doi: 10.1186/ bcr2819.

Beck MT, Peirce SK, Chen WY. 2002. Regulation of bcl-2 gene expression in human breast cancer cells by prolactin and its antagonist, hPRL-G129R. Oncogene 21: 5047-5055.

Ben-Jonathan N, Hnasko R. 2001. Dopamine as a prolactin (PRL) inhibitor. Endocr Rev 22: 724-763.

Ben-Jonathan N, Mershon JL, Allen DL, Steinmetz RW. 1996. Extrapituitary prolactin: Distribution, regulation, functions, and clinical aspects. Endocr Rev 17: 639-669.

Ben-Jonathan N, LaPensee CR, LaPensee EW. 2007. What can we learn from rodents about prolactin in humans? Endocr Rev 29: 1-41.

Biswas R, Vonderhaar BK. 1987. Role of serum in the prolactin responsiveness of MCF-7 human breast cancer cells in longterm tissue culture. Cancer Res 47: 3509-3514.

Bole-Feysot C, Goffin V, Edery M, Binart N, Kelly PA. 1998. Prolactin (PRL) and its receptor: Actions, signal transduction pathways and phenotypes observed in PRL receptor knockout mice. Endocr Rev 19: 225-268.

Boot LM, Ropcke G, Muhlbock O. 1962. Mammary tumour induction by pituitary isografts in mice. Acta Unio Int Contra Cancrum 18: 270-271.

Boyns AR, Buchan R, Cole EN, Forrest AP, Griffiths K. 1973. Basal prolactin blood levels in three strains of rat with differing incidence of 7,12-dimethylbenz(a)anthracene induced mammary tumours. Eur J Cancer 9: 169-171.

Brockman JL, Schuler LA. 2005. Prolactin signals via Stat5 and Oct-1 to the proximal cyclin D1 promoter. Mol Cell Endocrinol 239: 45-53.

Campbell GS, Argetsinger LS, Ihle JN, Kelly PA, Rillema JA, Carter-Su C. 1994. Activation of JAK2 tyrosine kinase by prolactin receptors in $\mathrm{Nb} 2$ cells and mouse mammary gland explants. Proc Natl Acad Sci 91: 5232-5236.

Chan CB, Liu X, Ensslin MA, Dillehay DL, Ormandy CI, Sohn P, Serra R, Ye K. 2010. PIKE-A is required for prolactinmediated STAT5a activation in mammary gland development. EMBO J 29: 956-968.

Chen CC, Boxer RB, Stairs DB, Portocarrero CP, Horton RH, Alvarez JV, Birnbaum MJ, Chodosh LA. 2010. Akt is required for Stat 5 activation and mammary differentiation. Breast Cancer Res 12: R72. doi: 10.1186/bcr2640.

Chen CC, Stairs DB, Boxer RB, Belka GK, Horseman ND, Alvarez JV, Chodosh LA. 2012. Autocrine prolactin induced by the Pten-Akt pathway is required for lactation initiation and provides a direct link between the Akt and Stat5 pathways. Genes Dev 26: 2154-2168.

Clevenger CV. 2003. Role of prolactin/prolactin receptor signaling in human breast cancer. Breast Dis 18: 75-86.

Clevenger CV, Chang WP, Ngo W, Pasha TL, Montone KT, Tomaszewski JE. 1995. Expression of prolactin and prolactin receptor in human breast carcinoma. Evidence for an autocrine/paracrine loop. Am J Pathol 146: 695-705.

DaSilva L, Howard OM, Rui H, Kirken RA, Farrar WL. 1994. Growth signaling and JAK2 association mediated by membrane-proximal cytoplasmic regions of prolactin receptors. I Biol Chem 269: 18267-18270.

David M, Petricoin EF 3rd, Igarashi K, Feldman GM, Finbloom DS, Larner AC. 1994. Prolactin activates the interferonregulated $\mathrm{p} 91$ transcription factor and the Jak2 kinase by tyrosine phosphorylation. Proc Natl Acad Sci 91: 71747178.

Dusanter-Fourt I, Muller O, Ziemiecki A, Mayeux P, Drucker B, Djiane J, Wilks A, Harpur AG, Fischer S, Gisselbrecht S. 1994. Identification of JAK protein tyrosine kinases as signaling molecules for prolactin. Functional analysis of prolactin receptor and prolactin-erythropoietin receptor chimera expressed in lymphoid cells. EMBO J 13: 2583-2591.

Frank SJ. 2002. Minireview: Receptor dimerization in GH and erythropoietin action-it takes two to tango, but how? Endocrinology 143: 2-10.

Gerlo S, Davis JRE, Mager DL, Kooijman R. 2006. Prolactin in man: A tale of two promoters. Bioessays 28: 1051-1055.

Ginsburg E, Vonderhaar BK. 1995. Prolactin synthesis and secretion by human breast cancer cells. Cancer Res 55: 2591-2595.

Gouilleux F, Wakao H, Mundt M, Groner B. 1994. Prolactin induces phosphorylation of Tyr694 of Stat5 (MGF), a prerequisite for DNA binding and induction of transcription. EMBO J 13: 4361-4369.

Hankinson SE, Willett WC, Michaud DS, Manson JE, Colditz GA, Longcope C, Rosner B, Speizer FE. 1999. Plasma prolactin levels and subsequent risk of breast cancer in postmenopausal women. J Natl Cancer Inst 91: 629-634. 
Harvey PW. 2011. Hypothesis Prolactin is tumorigenic to human breast: Dispelling the myth that prolactin-induced mammary tumors are rodent-specific. J Appl Toxicol 32: 1-9.

Horseman ND, Zhao W, Montecino-Rodriguez E, Tanaka M, Nakashima K, Engle SJ, Smith F, Markoff E, Dorshkind K. 1997. Defective mammopoiesis, but normal hematopoiesis, in mice with a targeted disruption of the prolactin gene. EMBO J 16: 6926-6935.

Huang Y, Li X, Jiang J, Frank SJ. 2006. Prolactin modulates phosphorylation, signaling and trafficking of epidermal growth factor receptor in human T47D breast cancer cells. Oncogene 25: 7565-7576.

Ingram DM, Nottage EM, Roberts AN. 1990. Prolactin and breast cancer risk. Med I Aust 153: 469-473.

Jahn GA, Edery M, Belair L, Kelly PA, Djiane J. 1991. Prolactin receptor gene expression in rat mammary gland and liver during pregnancy and lactation. Endocrinology 128: 29762984.

LaPensee EW, Schwemberger SI, LaPensee CR, Bahassi EM, Afton SE, Ben-Jonathan N. 2009. Prolactin confers resistance against cisplatin in breast cancer cells by activating glutathione-S-transferase. Carcinogenesis 30: 1298-1304.

Malarkey WB, Kennedy M, Allred LE, Milo G. 1983. Physiological concentrations of prolactin can promote the growth of human breast tumor cells in culture. I Clin Endocrinol Metab 56: 673-677.

Manhes C. 2006. Local over-expression of prolactin in differentiating mouse mammary gland induces functional defects and benign lesions, but no carcinoma. J Endocrinol 190: 271285.

Maus MV, Reilly SC, Clevenger CV. 1999. Prolactin as a chemoattractant for human breast carcinoma. Endocrinology 140: 5447-5450.

Meltzer HY, Fang VS. 1976. The effect of neuroleptics on serum prolactin in schizophrenic patients. Arch Gen Psychiatry 33: 279-286.

Mershon J, Sall W, Mitchner N, Ben-Jonathan N. 1995. Prolactin is a local growth factor in rat mammary tumors. Endocrinology 136: 3619-3623.

Miller SL. 2005. Novel association of Vav2 and Nek3 modulates signaling through the human prolactin receptor. Methods Enzymol 19: 939-949.

Miller SL, Antico G, Raghunath PN, Tomaszewski JE, Clevenger CV. 2007. Nek3 kinase regulates prolactin-mediated cytoskeletal reorganization and motility of breast cancer cells. Oncogene 26: 4668-4678.

Nagano M, Kelly PA. 1994. Tissue distribution and regulation of rat prolactin receptor gene expression. Quantitative analysis by polymerase chain reaction. I Biol Chem 269: 1333713345 .

Naylor MJ, Lockefeer JA, Horseman ND, Ormandy CJ. 2003. Prolactin regulates mammary epithelial cell proliferation via autocrine/paracrine mechanism. Endocrine 20: 111-114.

Neilson LM, Zhu J, Xie J, Malabarba MG, Sakamoto K, Wagner K-U, Kirken RA, Rui H. 2007. Coactivation of Janus Tyrosine Kinase (Jak)1 positively modulates prolactin-Jak 2 signaling in breast cancer: Recruitment of ERK and signal transducer and activator of transcription (Stat) 3 and enhancement of Akt and Stat5a/b pathways. Methods Enzymol 21: 22182232.

Ormandy CJ, Camus A, Barra J, Damotte D, Lucas B, Buteau H, Edery M, Brousse N, Babinet C, Binart N, et al. 1997. Null mutation of the prolactin receptor gene produces multiple reproductive defects in the mouse. Genes Dev 11: 167-178.

Rider L, Diakonova M. 2011. Adapter protein SH2B1 binds filamin A to regulate prolactin-dependent cytoskeletal re- organization and cell motility. Methods Enzymol 25: 12311243.

Rider L, Shatrova A, Feener EP, Webb L, Diakonova M. 2007. JAK2 tyrosine kinase phosphorylates PAK1 and regulates PAK1 activity and functions. J Biol Chem 282: 30985-30996.

Rose-Hellekant TA, Arendt LM, Schroeder MD, Gilchrist K, Sandgren EP, Schuler LA. 2003. Prolactin induces ER $\alpha$ positive and $E R \alpha$-negative mammary cancer in transgenic mice. Oncogene 22: 4664-4674.

Rui H, Lebrun JJ, Kirken RA, Kelly PA, Farrar WL. 1994. JAK2 activation and cell proliferation induced by antibody-mediated prolactin receptor dimerization. Endocrinology 135: 12991306.

Sakamoto K, Creamer BA, Triplett AA, Wagner K-U. 2007. The Janus kinase 2 is required for expression and nuclear accumulation of cyclin D1 in proliferating mammary epithelial cells. Methods Enzymol 21: 1877-1892.

Schroeder MD, Symowicz J, Schuler LA. 2002. PRL modulates cell cycle regulators in mammary tumor epithelial cells. Mol Endocrinol 16: 45-57.

Scotti ML, Langenheim JF, Tomblyn S, Springs AE, Chen WY. 2008. Additive effects of a prolactin receptor antagonist, G129R, and herceptin on inhibition of HER2-overexpressing breast cancer cells. Breast Cancer Res Treat 111: 241-250.

Tworoger SS, Eliassen AH, Sluss P, Hankinson SE. 2007. A prospective study of plasma prolactin concentrations and risk of premenopausal and postmenopausal breast cancer. J Clin Oncol 25: 1482-1488.

Vonderhaar BK. 1989. Estrogens are not required for prolactin induced growth of MCF-7 human breast cancer cells. Cancer Lett 47: 105-110.

Vonderhaar BK. 1999. Prolactin involvement in breast cancer. Endocr Relat Cancer 6: 389-404.

Wakao H, Gouilleux F, Groner B. 1994. Mammary gland factor (MGF) is a novel member of the cytokine regulated transcription factor gene family and confers the prolactin response. EMBO J 13: 2182-2191.

Wang PS, Walker AM, Tsuang MT, Orav EJ, Glynn RJ, Levin R, Avorn J. 2002. Dopamine antagonists and the development of breast cancer. Arch Gen Psychiatry 59: 1147-1154.

Welsch CW, Nagasawa H. 1977. Prolactin and murine mammary tumorigenesis: A review. Cancer Res 37: 951-963.

Welsch CW, Dombroske SE, McManus MJ, Calaf G. 1979. Effect of human, bovine and ovine prolactin on DNA synthesis by organ cultures of benign human breast tumours. Br I Cancer 40: $866-871$.

Wennbo H, Gebre-Medhin M, Gritli-Linde A, Ohlsson C, Isaksson OG, Törnell J. 1997. Activation of the prolactin receptor but not the growth hormone receptor is important for induction of mammary tumors in transgenic mice. J Clin Invest 100: 2744-2752.

Wieck A, Haddad P. 2002. Hyperprolactinaemia caused by antipsychotic drugs. BM/ 324: 250-252.

Yamauchi T. 2000. Constitutive tyrosine phosphorylation of ErbB-2 via Jak2 by autocrine secretion of prolactin in human breast cancer. J Biol Chem 275: 33937-33944. 


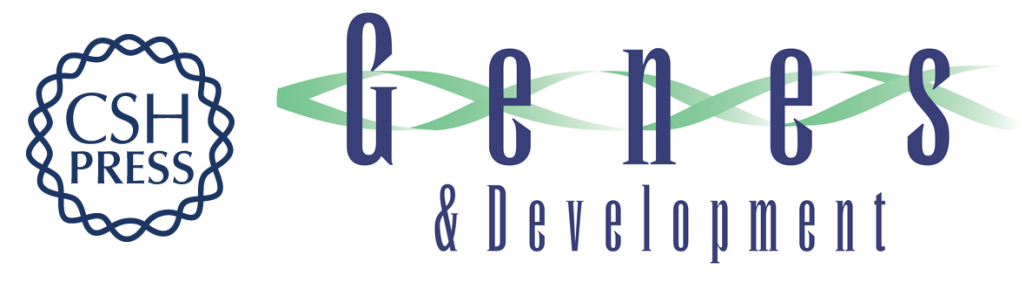

\section{Autocrine prolactin: an emerging market for homegrown (prolactin) despite the imports}

Senthil K. Muthuswamy

Genes Dev. 2012, 26:

Access the most recent version at doi:10.1101/gad.204636.112
Related Content Autocrine prolactin induced by the PtenAkt pathway is required for lactation initiation and provides a direct link between the Akt and Stat5 pathways Chien-Chung Chen, Douglas B. Stairs, Robert B. Boxer, et al. Genes Dev. October , 2012 26: 2154-2168
References This article cites 60 articles, 16 of which can be accessed free at: http://genesdev.cshlp.org/content/26/20/2253.full.html\#ref-list-1
Articles cited in:
http://genesdev.cshlp.org/content/26/20/2253.full.html\#related-urls

\section{License}
Email Alerting Service

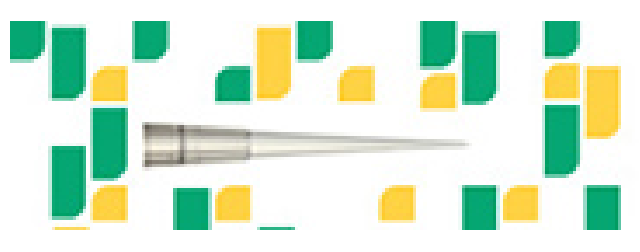

